Litteratur

1. Hauge JG, Aakvaag RK, Christensen TB. Biokjemi: en grunnbok. 4. utg. Oslo: Universitetsforlaget 2001

2. Harvey RA, Ferrier DR. Biochemistry. 5. utg. New York, NY: Lippincott, 2011.

\section{Etiske dilemmaer ved forskningsbiobanker}

Jan Helge Solbakk, Søren Holm, Bjørn Hofmann, red.

The ethics of research biobanking

357 s, ill. Heidelberg: Springer, 2010.

Pris USD 189

ISBN 978-0-387-93871-4

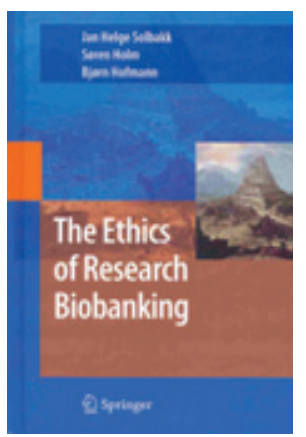

Boken er resultat av et internasjonalt forskningssamarbeid som har pågått siden 2004 mellom åtte land: Danmark, Island, Portugal, Frankrike, Norge, Sverige, Storbritannia og USA. Samarbeidet er finan-

siert gjennom Norges forskningsråd og Folkehelseinstituttet. Redaksjonskomiteen er norsk og dansk.

Det er to hoveddeler. Den første delen består av ti kapitler, den andre av 11 kapitler. Enkelte forfattere står bak flere av kapitlene, som i stor grad er utformet som selvstendige artikler. Temaene spenner over et vidt felt, fra informert samtykke og dugnadsaspekt til eierskap og lovregulering. Forskningsbiobanker og etiske utfordringer er en fellesnevner gjennom hele boken. Foran finner man en liste over artikkelforfatterne med en kort bibliografi. Hvert kapittel avsluttes med en fyldig referanseliste. Boken er innbundet med oversiktlig layout. Målgruppen er et bredt publikum: forvaltere og brukere av biobanker innen medisinsk forskning, helsepolitikere, lovgivere og pasienter og friske donorer av biologisk materiale.

Man kan med fordel lese boken i sin helhet, men kapitlene kan også leses som selvstendige bidrag. En ulempe er at flere av forfatterne kommer fra akademiske miljøer innen filosofi og etikk, noe som gjør boken ujevn med hensyn til tilgjenglighet og relevans for de av oss som ikke til daglig arbeider med den akademiske diskurs. Jeg savner en kort forklaring i slutten av hvert kapittel for enkelte av de termene som dukker opp, som poststrukturalisme, Kants autonomibegrep, hermeneutikk etc. Det er synd hvis språket virker avskrekkende, fordi forfatterne tar opp mange høyst relevante og viktige problemstillinger.

Internasjonalt er det en økende debatt om regulering og forvaltning av forskningsbiobanker. Biobankvirksomhet har eksistert $i$ lang tid som en viktig del av medisinsk forskning, men medisinsk teknologi har medført økende etterspørsel etter biologisk materiale og tilhørende data. Ordet biobank oppsto i midten av 1990-årene, sannsynligvis først i Danmark. I dag bruker man fortsatt ordet biobank forskjellig, hvilket gjenspeiles i lovverk, direktiver og konvensjoner. I Tyskland definerer man biobank som biologisk materiale og tilhørende data, noe som den norske biobankloven fra 2003 gjorde for forskningsbiobankene frem til den ble erstattet av helseforskningsloven i 2009. Nå definerer man en forskningsbiobank kun som biologisk materiale, som oppbevares over en viss tid (ca. to måneder). På Island omfatter lovreguleringen biobanker som biologisk materiale oppbevart evig. Forskjeller i lands definisjoner og lovregulering av biobanker er et av mange tema som forfatterne diskuterer i den andre delen.

Det som skiller denne boken fra en del andre om samme tema, er vektleggingen av det etiske aspektet og viljen til nytenkning, noe som reflekteres i inndelingen. Første del omhandler temaer som informert samtykke, betydningen av genetisk informasjon, tilbakemelding av resultater til prosjektdeltaker, reservasjonsrett fremfor samtykke og donors plikter og rettigheter. Forholdet mellom forsker og donor, betydningen av tillit til helsevesenet, gevinster ved etablering av populasjonsbaserte biobanker er andre aktuelle temaer. Forfatterne bruker relevante eksempler i argumentasjonen, som det norske MIDIA-prosjektet. I den andre delen diskuterer de bl.a. språkets betydning for hvordan forskningsbiobanker oppfattes og reguleres, dvs. en analogisk eller metaforisk tilnærming. Hvorvidt biobank defineres som overskuddsmateriale, med assosiasjon til noe som likevel skal kastes, del av en bank med assosiasjon til innskudd og uttak, biologisk forsikring, f.eks. ved oppbevaring av navlestrengsblod, får konsekvenser for hvilke holdninger donor og forsker får til den aktuelle biobanken. Det argumenteres for at vi i stedet for biobank bør bruke ord som biotek (biologisk bibliotek), og biologisk (kunst)galleri, som vil kunne gi nye tilnærminger til forvaltning av biobanker, i stedet for assosiasjoner til markedsmekanismer. I siste kapittel minner forfatterne om at etikk må være en integrert del av arbeidet for en europeisk harmonisering av lovregulering innen biobank.

Boken er noe tung å lese, men jeg anbefaler den likevel for lovgivere og andre med forvaltningsansvar for biobanker.

\section{Wenche Reed}

Stab forskning og utvikling

Oslo universitetssykehus

\section{Bredde og dybde}

Dora Kohen, red.

Oxford textbook of women and mental health

333 s, tab, ill. Oxford: Oxford University Press, 2010. Pris CHF 56

ISBN 978-0-19-921436-5

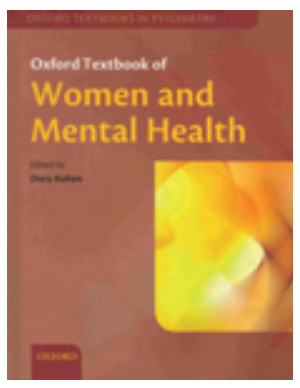

Intet kan forstås uten sammenlikningsgrunnlag. Denne boken med utgangspunkt i kvinner er en glimrende psykiatrisk lærebok som setter sammen biologi, psykologi, sosiologi/sosiale

forhold og tro/kultur i sin forståelse av psykiske lidelser. 56 bidragsytere, $i$ alt vesentlig fra Storbritannia, har i 35 kapitler fordelt på seks emneområder reist en bauta over den nå avdøde redaktøren. De har virkelig lyktes i å hedre hennes minne.

I første del konsentrerer forfatterne seg om grunnleggende aspekter for psykisk helse, med kvinner som utgangspunkt. Stigma, vold, etnisitet, kjønnsforskjeller, seksuell identitet, tilknytning, foreldrerollen og det å være omsorgsperson blir godt belyst. Hele tiden benytter de epidemiologiske data, biologiske forskningsfunn og andre relevante data, som kanskje ikke alltid er de første man tenker på. Kvinner og menns uunngåelige samhørighet, og barnas likeledes utvikling, avhengig av de voksne, er stadig med.

Del to har kliniske kapitler. Epidemiologisk sett er forekomsten av schizofreni, alvorlig bipolar lidelse og tvangslidelser likt fordelt mellom kvinner og menn, selv om utformingen kan være ulik. Angst, depresjon og bordeline personlighetstrekk finnes hos en overvekt av kvinner. Hvorfor det, og hvordan behandle tilstandene? Her er det mye å velge mellom, og en god oversikt. Særlig kapitlene om behandling av borderline og selvskading er inspirerende. Avsnittet om perinatale lidelser er en kraftig påminnelse om et ofte forsømt område. Den svakeste delen er kapitlene om rusmisbruk.

Forfatterne skriver fengende om spiseforstyrrelser, posttraumatisk stresslidelse, selvskading, suicid og medisinsk uforklarte symptomer i del tre. Del fire handler om betydningen for neste generasjon av foreldres psykiske lidelser, del fem om lærevansker og intellektuell funksjonshemning. Til sist er det et avsnitt om (britisk) lovgivning og retning videre, med kvinners psykiske helse som utgangspunkt

Det er gode overskrifter, korte avsnitt og mange referanser. Forfatterne nevner aktuelle spørreskjemaer og gir oversikt over forskjellige måter å forstå lidelser eller fenomener på, og forskjellige måter å møte dem på. 
Alt $i$ alt er dette en bok hvor man setter sammen filosofiske, sosiale og naturvitenskapelige rammer om menneskenes liv og mentale helse fra fødsel til alderdom og død.

I en tid med økende standardisering og bruk av strukturerte skjemaer til diagnose, forståelse og behandling kan denne boken bidra til at den enkelte helsearbeideren beholder perspektiv og dybdesyn. Boken beriker, pirrer nysgjerrigheten og stimulerer til å tenke selv.

\section{Inger Sandanger}

Voksenpsykiatri (VOP)

Nordlandssykehuset Lofoten Leknes

\section{Kunnskapsbasert urologi}

Philipp Dahm, Roger Dmochowski, red. Evidence-based urology

432 s, tab, ill. Chichester: Wiley-Blackwell, 2010. Pris GBP 100

ISBN 978-1-4051-8594-3

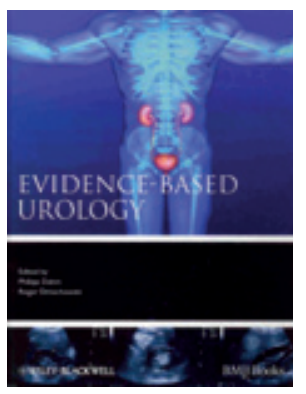

Jeg anbefaler denne boken til alle som ønsker lærdom om kunnskapsbasert urologi, og det bør gjelde alle som praktiserer i faget - både utdanningskandidater og spesialister. Forfat-

terne er en rekke anerkjente kapasiteter som i det vesentlige kommer fra USA og Canada, men Europa og Australia er også representert.

I de første seks kapitlene tar forfatterne for seg bakgrunnen for kunnskapsbasert urologi - hvordan man søker, bedømmer og tolker vitenskapelige artikler. Boken har 40 kapitler, og forfatterne går grundig gjennom litteratur hvor vekten er lagt på gode kliniske studier og metaanalyser. Både medisinsk og kirurgisk behandling av de fleste urologiske problemstillinger blir grundig belyst. Forfatterne søker å utdype flere konkrete spørsmål i hvert kapittel. Hvert spørsmål ender opp med anbefalinger som deles i grad 1 eller grad 2, dersom anbefalingen som gis, er sterk eller svak. Dette etterfølges av en bokstav (A-D) ettersom kvaliteten av evidens er sterk, middels, svak eller meget svak. Som eksempel spør forfatterne om dvergpalmeekstrakt (saw palmetto) har effekt som behandling av symptomatisk prostataforstørrelse. Etter at de har gått gjennom litteraturen blir konklusjonen at det ikke har objektiv effekt med anbefaling $1 \mathrm{~A}$

Det er lett å lese konklusjonen ved at svaret på relevante spørsmål også fremstilles grafisk (forest plot). På denne måten ser man enkelt om resultatene samler seg på den ene eller andre siden av en midtlinje.

Hva er de beste prediktorene for nefrektomi etter abdominalt traume? Er det trygt å bruke antimuskarine midler ved overaktiv blære? Hva er effekten av behandling med alfaadrenerge blokkere på avgang av ureterkonkrementer? Bedres resultatet etter radikal prostatektomi om man gir adjuvant strålebehandling ved pT3 eller pT2 med ufrie marginer? Hvilken klasse antibiotika kan anbefales ved behandling av urinveisinfeksjoner? Hjelper inntak av tranebær for å redusere risikoen for ny infeksjon? Dette er eksempler på kliniske problemstillinger som forfatterne belyser.

Boken innholder til sammen henimot 1700 referanser. Av disse har jeg sporet opp 12 artikler med norske forfatternavn, og av dem er bare to urologer. Den ene artikkelen er en oversiktsartikkel skrevet sammen med flere utenlandske medforfattere, og den andre er utført i Danmark. Dette forteller dessverre noe om den norske forskningsaktiviteten på dette fagområdet.

\section{Trygve Talseth}

Seksjon for rekonstruktiv urologi

og nevrourologi

Urologisk avdeling

Klinikk for kirurgi og kreft

Oslo universitetssykehus

\section{Søvnforstyrrelser ved psykiske lidelser}

S.R. Pandi-Perumal, Milton Kramer, red.

Sleep and mental illness

430 s, tab, ill. Cambridge: Cambridge University Press, 2010. Pris GBP 80

ISBN 978-0-521-11050-1

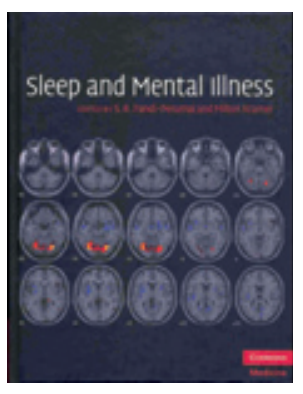

Sleep and mental illness er en lærebok hvor forfatterne tar sikte på å gi en presentasjon av søvn ved ulike psykiske lidelser. Målgruppen er alle som befatter seg med utredning og

behandling av pasienter med psykiske lidelser der søvnforstyrrelser utgjør en vesentlig del av symptombildet.

Boken er delt i tre deler: I den første delen tar forfatterne for seg basalforskningen rundt søvn og psykiske lidelser, inkludert forholdet mellom depresjon og søvn, arvens påvirkning på søvn og søvnendringer forårsaket av psykofarmaka. Den andre delen handler om de nevroendokrine endringene som man ser ved ulike psykiske lidelser. Den tredje delen er den største og består av en serie kliniske problemstillinger knyttet til søvn og psykiske lidelser. Her omtaler forfatterne temaer som søvn ved $\mathrm{AD} / \mathrm{HD}$, demens, autisme, schizofreni, spiseforstyrrelser, borderline personlighetsforstyrrelse og hodeskader.

Søvnforstyrrelser finner man nesten alltid ved psykisk lidelse, men det er begrenset kunnskap om søvnlidelser er en konsekvens av psykiske lidelser, eller omvendt. Det som er sikkert, er at samvariansen er høy. Man antar at om lag 50-80\% av pasienter med en psykisk lidelse har søvnforstyrrelser, og at ca. $50 \%$ av pasienter med kronisk insomni har en psykisk lidelse.

Sleep and mental illness består av 36 kapitler som er skrevet av 72 forfattere. De to redaktørene, Pandi-Perumal og Kramer, er henholdsvis søvnforsker og professor i psykiatri. Forfatterne er et knippe av de fremste søvnekspertene i verden. Kapitlene varierer i omfang og presentasjonsmåte, slik det gjerne blir når det er mange forfattere involvert. Bruk av bilder og illustrasjoner er ganske begrenset. En del av fagstoffet er slik presentert at noe bakgrunnsviten om søvnmedisin er nødvendig for å kunne få fullt utbytte av det. Nedslagsfeltet er nok derfor ikke like bredt som forlaget vil ha det til.

Bidragsyterne gir en god, oppdatert fremstilling av hva vitenskapen hittil har greid å kartlegge om søvnendringer ved psykiske lidelser. Det er mye man ikke vet, men det man vet, er i det store og hele samlet mellom disse permene.

\section{Arne Fetveit}

Institutt for helse og samfunn

Universitetet i Oslo

\section{Kortfattet immunologi for leger}

\author{
Ian Todd, Gavin Spickett \\ Immunology \\ Lecture notes. 6. utg. 232 s, tab, ill. Chichester \\ Wiley-Blackwell, 2010. Pris GBP 30 \\ ISBN 978-1-4051-9136-4
}

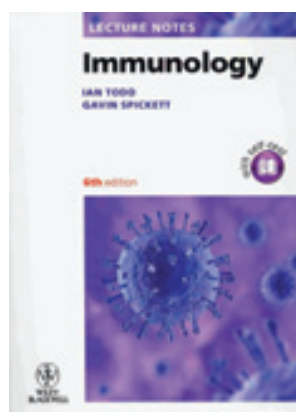

Immunologi griper inn i de aller fleste medisinske fagdisipliner f.eks. er immunologiske mekanismer sentrale i alle inflammatoriske tilstander. Derfor er det synd at mange leger føler at de ikke forstår immunologi. Immunologi er kanskje et av 